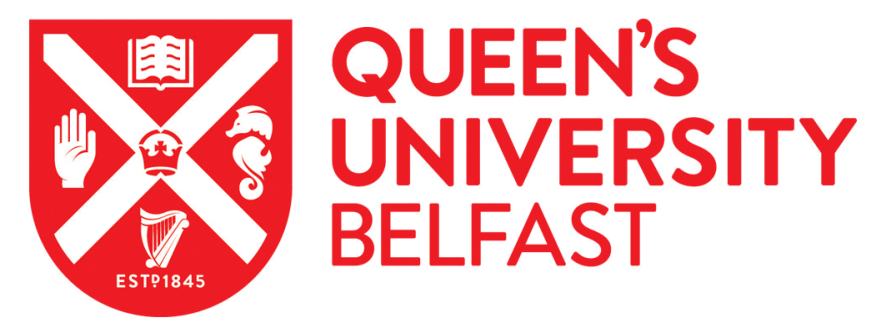

\title{
Arsenic and Fluoride Removal from Contaminated Drinking Water with Haix-Fe-Zr and Haix-Zr Resin Beads
}

Phillips, D. H., Sen Gupta, B., Mukhopadhyay, S., \& Sen Gupta, A. K. (2018). Arsenic and Fluoride Removal from Contaminated Drinking Water with Haix-Fe-Zr and Haix-Zr Resin Beads. Journal of Environmental Management, 215, 132-142. https://doi.org/10.1016/j.jenvman.2018.03.018

Published in:

Journal of Environmental Management

Document Version:

Peer reviewed version

Queen's University Belfast - Research Portal:

Link to publication record in Queen's University Belfast Research Portal

Publisher rights

(C) 2018 Elsevier Ltd.

This manuscript version is made available under the CC-BY-NC-ND 4.0 license http://creativecommons.org/licenses/by-nc-nd/4.0/,which permits distribution and reproduction for noncommercial purposes, provided the author and source are cited.

\section{General rights}

Copyright for the publications made accessible via the Queen's University Belfast Research Portal is retained by the author(s) and / or other copyright owners and it is a condition of accessing these publications that users recognise and abide by the legal requirements associated with these rights.

Take down policy

The Research Portal is Queen's institutional repository that provides access to Queen's research output. Every effort has been made to ensure that content in the Research Portal does not infringe any person's rights, or applicable UK laws. If you discover content in the Research Portal that you believe breaches copyright or violates any law, please contact openaccess@qub.ac.uk. 


\title{
Arsenic and Fluoride Removal from Contaminated Drinking Water with Haix-Fe-Zr and Haix-Zr Resin Beads
}

\author{
Debra H. Phillips ${ }^{1}$, Bhaskar Sengupta ${ }^{2}$, Soumyadeep Mukhopadhyay ${ }^{3}$, and Arup K. \\ Sengupta ${ }^{4}$ \\ ${ }^{1}$ School of Natural and Built Environment, Queen's University of Belfast, Belfast, Northern \\ Ireland, UK \\ ${ }^{2}$ Water Academy, School of Energy, Geoscience, Infrastructure and Society, Heriot-Watt \\ University, Edinburgh, Scotland, UK \\ ${ }^{3}$ Scientific Event Ltd, 31, Cannon Street, Seton Park, Winchburgh, Broxburn, Scotland, UK \\ ${ }^{4}$ Department of Civil and Environmental Engineering, Lehigh University, Bethlehem, \\ Pennsylvania, USA
}

Haix-Fe- $\mathrm{Zr}$ and Haix- $\mathrm{Zr}$ resin beads in the removal of $\mathrm{As}(\mathrm{III}), \mathrm{As}(\mathrm{V})$ and $\mathrm{F}^{-}$from

groundwater with a similar geochemistry to a site where a community-based drinking water plant has been installed in West Bengal, India. The groundwater was spiked separately with $\sim 200 \mu \mathrm{g} / \mathrm{L} \mathrm{As}(\mathrm{III})$ and $\mathrm{As}(\mathrm{V})$ and $5 \mathrm{mg} / \mathrm{L} \mathrm{F}^{-}$. Haix-Zr resin beads were more effective than

Haix-Fe-Zr resin beads in removing As(III) and As(V). Haix-Zr resin beads showed higher

removal of $\mathrm{As}(\mathrm{V})$ compared to As(III). Haix-Zr resin beads removed As(V) below the WHO $(10 \mu \mathrm{g} / \mathrm{L})$ drinking water standards at $8.79 \mu \mathrm{g} / \mathrm{L}$ after 4 hours of shaking, while As(III) was reduced to $7.72 \mu \mathrm{g} / \mathrm{L}$ after 8 hours of shaking. Haix-Fe-Zr resin beads were more effective in removing $\mathrm{F}^{-}$from the spiked groundwater compared to Haix- $\mathrm{Zr}$ resin beads. Concentrations of $\mathrm{F}^{-}$decreased from $6.27 \mathrm{mg} / \mathrm{L}$ to $1.26 \mathrm{mg} / \mathrm{L}$, which is below the WHO drinking water standards $(1.5 \mathrm{mg} / \mathrm{L})$ for $\mathrm{F}^{-}$, after 15 minutes of shaking with Haix-Fe-Zr resin beads. After 20 minutes of shaking in groundwater treated with Haix- $\mathrm{Zr}$ resin beads, $\mathrm{F}^{-}$concentrations decreased from $6.27 \mathrm{mg} / \mathrm{L}$ to $1.43 \mathrm{mg} / \mathrm{L}$. In the removal of $\mathrm{As}(\mathrm{III}), \mathrm{As}(\mathrm{V})$, and $\mathrm{F}^{-}$from the groundwater, Haix-Fe-Zr and Haix-Zr resin beads fit the parabolic diffusion equation (PDE) suggesting that adsorption of these contaminants was consistent with inter-particle diffusion. 
1 Keywords: Arsenic contaminated drinking water, Fluoride contaminated drinking water;

2 Haix-Zr beads; Haix-Fe beads; adsorption; drinking water treatment

3

4

5

6

\section{Introduction}

Arsenic and $\mathrm{F}^{-}$contamination of water resources are rapidly spreading globally, necessitating an urgent need to provide safe drinking water to these areas. Drinking water harvested from underground sources in many parts of the world, especially in India, contain concentrations of As well above the Bureau of Indian Standards BIS:10500 (BIS, 2012), World Health Organization (WHO, 2011) and US Environmental Protection Agency (EPA) limits of $10 \mu \mathrm{g} / \mathrm{L}$ (EPA, 2001). The As contamination of drinking water in the GangaMeghna-Brahmaputra (GMB) plain with an area of $569,749 \mathrm{~km}^{2}$ and a population of $>500$ million covering a large area of Bangladesh and India, is considered one of the worse catastrophes in recent times (Ravenscroft et al., 2005; Bhattacharya et al., 2007; Bundschuh, 2012). This crisis affects millions of people and has spread to Northeast Asia, affecting Vietnam, Cambodia, Laos, Myanmar, and other nearby countries (Berg et al., 2007; Stanger et al., 2005; Bearak, 1998). Initial stages of health effects, referred collectively as arsenicosis, usually manifests after about 10 years of chronic exposure of $>50 \mathrm{mg} / \mathrm{L}$ of As. Common arsenicosis manifests as skin lesions, particularly in the palm of the hands and bottom of the feet, which over time become cancerous and eventually lead to gangrene. Lung, bladder, and kidney cancer are associated with later stages of arsenicosis (Bagla and Kaiser, 1996). To add to this crisis, growing agricultural demand and increased populations have resulted in excessive groundwater withdrawals, which have increased the dissolution of As due to weathering of minerals in the aquifers (Bagla and Kaiser, 1996).

Fluoride contamination is commonly high in soil and rock materials in arid regions. The North-western states and the Deccan Plateau region of India are especially affected. 
1 Elevated concentrations of $\mathrm{F}^{-}$can occur in drinking water from a range of groundwater

2 sources. It is well known that a very small amount of $\mathrm{F}^{-}$is good for the teeth and bones.

3 However, prolonged consumption of $\mathrm{F}^{-}$contaminated groundwater $>1.5 \mathrm{mg} / \mathrm{L} /$ day can lead to

4 fluorosis (mainly skeletal and dental), especially if the person is malnourished

5 (Krishnamachari, 1976). Fluorosis is a growing world-wide problem estimated to affect 200

6 million people from 25 nations (Raj and Umayorubhagan, 2013). Additionally, there is

7 evidence that the rapid spread of elevated concentrations of $\mathrm{F}^{-}$in drinking water collected

8 from shallow wells is linked to soil degradation (Jaglan and Qureshi, 1996; Jacks et al., 9 2005).

Most of the populations suffering the effects of either As or $\mathrm{F}^{-}$contaminated groundwater are in impoverished rural communities in arid environments where temperatures are elevated resulting in the need to consume more water. Drinking of groundwater is preferred to surface water in these areas because it is more hygienic, tastes better and easily available. Therefore, it is crucial to set-up As and $\mathrm{F}^{-}$removal systems for drinking water on an emergency basis. Several As and $\mathrm{F}^{-}$removal technologies for safe drinking water have been developed over the last three decades and have gained wide-scale field applications, such as the Subterranean Arsenic Removal (SAR) technology which uses oxidation accelerated by autocatalytic effects of the oxidation products and chemo-autotrophic microorganisms (Sengupta et al., 2009). However, many of these technologies also use sorption onto iron, titanium, and zirconium oxides (Suzuki et al., 2000; Dutta et al., 2004, Bang et al., 2005; Aredes et al., 2013). A sorbent medium gaining wide-spread use is anion exchange resin beads, such as Haix-Fe, which use polymeric ligand exchange for selective As (Ramana and SenGupta, 1992). Haix-Fe resin beads installed in water treatment plants have had successful field applications in rural villages of India, especially in West Bengal, in treating As contaminated 
1 water with large columns connected to tube wells (Sengupta et al., 2009). Additionally, a

2 SAR plant has been retrofitted with a Haix column that acts as a polisher for supplying safe drinking water to a growing population (Mukhopadhyay et al., submitted). Groundwater is

4 pumped by electric water pumps or by hand to the top of the column and when the water

5 enters the column it is aerated. $\mathrm{Fe}^{2+}$ from the water is oxidized to $\mathrm{Fe}^{3+}$ which is then filtered

6 by the adsorbent bed. Hydrated Fe(III) oxide (HFO) nano-particles that form on top of anion

7 exchange Haix-Fe resin beads in the column help remove the As(V) and As(III) from the

8 water before it enters the resin bead section of the column. The resulting arsenic levels will

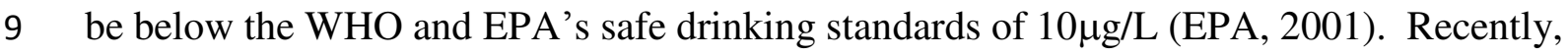

HAIX-Zr has been developed as an adsorbent that can be used in the community-based water treatment systems/columns that are currently using HAIX-Fe resin beads. HAIX-Zr is designed to treat $\mathrm{F}$ containing groundwater; however, its properties also allow it to treat As $(V)$ containing groundwater at a greater capacity compared to $\mathrm{F}^{-}$(Padungthon et al., 2014, 2015). These beads are durable as no physical or chemical degradation of the Haix-Zr resin beads have been observed after regeneration (Padungthon et al., 2015). By combining these metal oxide nano-particles of hydrated iron oxides with the chemically and mechanically stable polymeric ion exchange resins, a synergistic effect is created from enhancing the ligand sorption affinity of HFO and $\mathrm{HZrO}$ which is assisted by the Donnan membrane effect (Smith et al., 2015). Additional batch tests should be carried-out to validate this point. is supplying water to a growing population of people, therefore, a Haix column containing Haix-Fe resin beads has been retrofitted as a polishing unit onto the SAR water treatment plant. The groundwater had elevated As concentration in the range of $150 \mu \mathrm{g} / \mathrm{L}$, high above the WHO guideline (Mukhopadhyay et al., submitted). This project used groundwater with similar geochemical parameters to groundwater used as drinking water in a this village and 
1 nearby areas where $\mathrm{F}$ concentrations are also high. This project examines the potential to

2 use the Haix-Zr and Haix-Fe-Zr resin beads at this site and nearby sites. Although the

3 adsorption HAIX-Zr and HAIX-Fe resin beads have been investigated in other studies

4 (Ramana and SenGupta, 1992; Padungthon et al., 2014, 2015), this is the first time the new

5 hybrid HAIX-Fe-Zr resin beads have been investigated in the removal of As and F. As and F

6 contaminated groundwater is a crisis in Asia, especially in India (Ravenscroft et al., 2005;

7 Bhattacharya et al., 2007; Bundschuh, 2012) and is a growing world-wide concern (Berg et

8 al., 2007; Stanger et al., 2005; Bearak, 1998). The HAIX range of resin beads have

9 demonstrated great promise in removing As and F from drinking water, especially in

10 community based programmes, such as Drinkwell, where residents of villages are trained to

11 run the treatment plants and in larger commercial plants in the USA (SenGupta, 2017).

12 Additionally, these beads can be regenerated; therefore, they are a sustainable option for remediating As and F contaminated groundwater. However, more research is need in examining other hybrid HAIX resin beads, such as HAIX-Fe-Zr, in removing As and F. The objectives of this study are to examine the performance of Haix-Fe-Zr and Haix-Zr in the removal of As and $\mathrm{F}^{-}$from groundwater with similar characteristics to the contaminated groundwater from West Bengal.

\section{Materials and Methods}

\subsection{Resin Bead Properties}

\subsubsection{Haix-Fe-Zr Resin Beads}

Haix-Fe-Zr resin beads are small, approximately $0.5 \mathrm{~mm}$ to $1.5 \mathrm{~mm}$ in diameter (Figure 1a), with a reddish orange colour from hydrous ferric oxide (HFO) which range in size from 20-100nm. More detailed analysis by TEM reveals the HFOs as acicular and HZrOs as round platelet nano-particles present on the surface and within nano-porous Haix-Fe-Zr resin beads 
1 (Figure $1 \mathrm{~b}$ ). $\mathrm{HZrO}$ and $\mathrm{HFO}$ are precipitated on the gel-phase of the macro-porous anion

2 Haix exchange resin when they are synthesized (DeMarco et al., 2003) with quaternary

3 ammonium functional groups (Sengupta and Cumbal, 2007). These nano-sized Fe and $\mathrm{Zr}$

4 oxides are distributed along the surface and internally within the resin beads (Figure 1b) and

5 are responsible for the efficient removal of $\mathrm{As}$ and $\mathrm{F}^{-}$from contaminated water. Water flows

6 on the surface and within the beads through nano-sized voids where nano-Fe and $\mathrm{Zr}$ particles

7 are distributed (Figure $1 \mathrm{~b}$ ). This means large amounts of As and $\mathrm{F}^{-}$can be removed from the

8 contaminated water and absorbed on the surface and internal structure of the beads. This

9 adsorption can be explained by the high surface area created by the macro porosity of the

10 beads. Stereomicroscopic observations of polished sections of the Haix-Fe-Zr resin beads

11 show that the reddish HFOs mainly occur concentrically with the roundness of the bead

12 (Figure 1a). Each bed had individual patterns of HFO precipitation, although some beads had similar patterns.

\subsubsection{Haix-Zr Resin Beads}

Haix- $\mathrm{Zr}$ resin beads are beige/white coloured small $0.3 \mathrm{~mm}-1 \mathrm{~mm}$ macro porous anion exchange resin beads Figure 1c). TEM micrographs of polished sections of the Haix-Zr resin beads show the rounded/spherical sub-micron sized (ranging in size from 20nm-100nm) hydrated Zirconium $\left(\mathrm{Zr}^{4+}\right)$ oxides $(\mathrm{HZrO})$ particles distributed on their surface and within/through the ion exchange bead (Figure 1d). These nano-sized HZrO particles are responsible for the efficient removal of As and $\mathrm{F}^{-}$. This anion exchanger has a positively charged quaternary ammonium functional group, on which anionic ligands such as $\mathrm{As}(\mathrm{V})$ and $\mathrm{F}^{-}$can be absorbed. Water contaminated with $\mathrm{F}^{-}$and As flows through nano-sized pores within the beads (Figure 1d), where the nano-Zr oxide particles are dispersed. Large amounts 
1 of As and $\mathrm{F}^{-}$can be absorbed onto and within the beads due to the high surface area created

2 by their macro porosity similarly to Haix-Fe-Zr resin beads.

\subsection{Microscopic Analysis of Resin Beads}

5

6

\subsubsection{Stereomicroscopic and scanning electron microscopy}

Selected Haix-Fe-Zr and Haix-Zr resin beads were impregnated with an epoxy and polished so that the internal structure could be observed with a Nikon Stereomicroscope. Haix-Fe-Zr and Haix-Zr resin beads, after contact with As and $\mathrm{F}^{-}$spiked water, were also embedded in epoxy, polished and carbon coated and analyzed with a Jeol 6500 FEG (Jeol (UK) Ltd, Herts, England, UK) scanning electron microscope (SEM) equipped with an Oxford Instruments INCA Wave spectrometer for energy dispersive spectroscopy (EDS), back-scattered electron detector (BSE), and wavelength dispersive spectroscopy (WDS) (Oxford Instruments Plc, Oxford, England, UK).

\subsubsection{Transmission electron microscopy}

Samples for transmission electron microscopy (TEM) were dehydrated in a graded ethanol series $(30 \%, 50 \%, 70 \%, 90 \%, 100 \%)$. When dehydration was complete, the samples were transferred from $100 \%$ ethanol to acetone, from acetone to $30 \%$ Epon:Acetone mix, then to $50 \%$ Epon:Acetone mix, 70\% Epon:Acetone mix and finally to $100 \%$ Epon. To complete the resin infiltration, the samples were placed in $100 \%$ resin at ${ }^{+} 37^{\circ} \mathrm{C}$ for 2 hours. Following this, the samples were transferred into molds that were filled with fresh Epon and placed at ${ }^{+} 60^{\circ} \mathrm{C}$ for 24 hours until polymerisation was complete. Ultrathin $(80 \mathrm{~nm})$ sections were obtained from these blocks using a Leica EM UC6 ultramicrotome. The sections were collected on 200mesh/slot carbon-formvar copper grids and examined by transmission electron microscopy using a Tecnai G2 12 BioTWIN or Tecnai G2 20. 


\subsection{Selected Groundwater Source}

For the batch tests, groundwater samples were collected from a source in County Tyrone, Northern Ireland, which had a similar geochemistry as the groundwater on the site in West Bengal, India. The $\mathrm{pH}$ of the groundwater was measured with a Hach HQ40d multi meter using an IntelliCAL PHC101 pH probe (Hach Lange Manchester, UK). Metal concentrations in the groundwater were analyzed by inductively coupled plasma-optical emission spectroscopy (ICP-OES) using a PerkinElmer Optima 5300 DV (PerkinElmer, Waltham, MA, USA) employing argon as the cell gas for total $\mathrm{Ca}, \mathrm{Na}, \mathrm{Si}, \mathrm{Mg}$, and $\mathrm{Na}$. Anion concentrations in the groundwater sample were measured by ion chromatography (IC) using a Dionex DX500 system (Thermo Fisher Ireland Ltd, Dublin, Ireland), for fluoride (F ), chloride $\left(\mathrm{Cl}^{-}\right)$, nitrate $\left(\mathrm{NO}_{3}{ }^{-}\right)$, bicarbonate $\left(\mathrm{HCO}_{3}{ }^{-}\right)$and sulphate $\left(\mathrm{SO}_{4}{ }^{2-}\right)$. All samples were analysed in triplicate. The groundwater had a $\mathrm{pH}$ of $7.9,50 \mathrm{mg} / \mathrm{L} \mathrm{Ca}, 7 \mathrm{mg} / \mathrm{L} \mathrm{Mg}, 12 \mathrm{mg} / \mathrm{L} \mathrm{Na}$, $15 \mathrm{mg} / \mathrm{L} \mathrm{SiO}_{2}, 145 \mathrm{mg} / \mathrm{L} \mathrm{HCO}_{3}{ }^{-}, 20 \mathrm{mg} / \mathrm{L} \mathrm{SO}_{4}{ }^{2-}, 20 \mathrm{mg} / \mathrm{L} \mathrm{Cl}^{-}, 7 \mathrm{mg} / \mathrm{L} \mathrm{NO}_{3}{ }^{-}$, and $1.27 \mathrm{mg} / \mathrm{L} \mathrm{F}^{-}$.

The groundwater $\mathrm{pH}$ was reduced to $\mathrm{pH} 7$ with a few drops of $\mathrm{HCl}$. Groundwater was spiked with a stock solution of sodium arsenate dibasic heptahydrate $\left(\mathrm{Na}_{2} \mathrm{HAsO}_{4} \cdot 7 \mathrm{H}_{2} \mathrm{O}\right)$ in order to measure the arsenate $[\mathrm{As}(\mathrm{V})]$ and a stock solution of sodium (meta)arsenite $\left(\mathrm{NaAsO}_{2}\right)$ in order to measure arsenite $[\mathrm{As}(\mathrm{III})]$. Sodium fluoride $(\mathrm{NaF})$ was used to spike the groundwater with $\mathrm{F}^{-}$

\subsection{Sorption equilibrium - Batch tests}

Kinetic studies were used to compare the performance of the Haix-Fe- $\mathrm{Zr}$ and $\mathrm{Haix}-\mathrm{Zr}$ resin beads at removing As and $\mathrm{F}^{-}$. Haix-Fe-Zr and Haix-Zr resin beads (0.1gr-dry weight) were added to separate $200 \mathrm{~mL}$ screw capped conical flasks containing $100 \mathrm{ml}$ of groundwater spiked separately with $\sim 200 \mu \mathrm{g} / \mathrm{L}$ Arsenite [As(III)] and Arsenate [As(V)]. Haix-Fe-Zr and Haix-Zr resin beads (1.0gr-dry weight) were added to separate $200 \mathrm{~mL}$ screw capped conical 
1 flasks containing $100 \mathrm{~mL}$ of groundwater spiked with $5 \mathrm{mg} / \mathrm{L} \mathrm{F}^{-}$and shaken on an end-over-

2 end shaker at room temperature at $\sim 25^{\circ} \mathrm{C}$. The removal rate of the spiked As from

3 groundwater was examined by extracting and analyzing $1 \mathrm{~mL}$ of the solution from the bottles

4 collected at $0 \mathrm{~s}, 30 \mathrm{~s}, 1 \mathrm{~min}, 2 \mathrm{~min}, 5 \mathrm{~min}, 10 \mathrm{~min}, 30 \mathrm{~min}, 1 \mathrm{~h}, 4 \mathrm{~h}, 8 \mathrm{~h}, 24 \mathrm{~h}$, and 1 week. The

5 samples were stored under refrigeration and analysed quickly. All reagents used were of

6 analytical grade. Arsenic speciation was determined by ion chromatography with a Thermo

7 Dionex IC5000 Ion Chromatograph (Thermo Scientific) coupled with inductively coupled

8 plasma mass spectrometry using an iCap Q ICP-MS (Thermo Scientific). The removal rate

9 of $\mathrm{F}^{-}$was examined at similar times as the As spiked groundwater, except it was measured

10 with a Hach HQ40d multimeter equipped with a Hach ISEF 121 ion probe (Hach Lange

11 Manchester, UK). As(III), As(V) and fluoride were measured in triplicate. The amount of

12 As and $\mathrm{F}^{-}$sorbed onto the resins were calculated by the difference between the amounts added and/or already present in the water and that left in solution after equilibrium. Percent removal of As and $\mathrm{F}^{-}$was calculated as:

15 Percent Removal $(R \%)=\frac{C_{0}-C_{e}}{C_{0}} \times 100$

where Co is the initial concentration, $\mathrm{Ce}$ is the new concentration.

\subsection{Kinetic modeling of arsenic and fluoride adsorption}

Kinetic data for $\mathrm{As}(\mathrm{III}), \mathrm{As}(\mathrm{V})$ and $\mathrm{F}^{-}$were fitted in zero order, first order, second order, and parabolic diffusion equation (PDE) models in order to examine the arsenic and fluoride desorption mechanisms. The equations are given below. The best fit model was determined by the values of determination coefficients $\left(\mathrm{R}^{2}\right)$ and standard errors $(\mathrm{SE})$.

Zero order:

First order:

Second order:

Parabolic diffusion equation:

$$
\begin{aligned}
& {[C]_{t}=-k t+[C]_{0}} \\
& \ln [C]=-k t+\ln \left[C_{0}\right] \\
& 1 /[C]=1 /\left[C_{0}\right]+k t \\
& \mathrm{C} / \mathrm{C}_{\max }=\mathrm{A}+\mathrm{Dt}^{1 / 2}
\end{aligned}
$$


2 where $C$ is adsorbed pollutant $(\mathrm{As}(\mathrm{III}), \mathrm{As}(\mathrm{V})$ or $\mathrm{F})$ at any time, $C_{\max }$ is the maximum amount of

contaminant adsorbed from the solution, $t$ is the time, $A$ is the parameter of the equations, $k$ is the constant, and $\mathrm{D}$ is the diffusion constant. The $\mathrm{R}^{2}$ and model parameters were calculated using linear regression. MS Excel was used for the calculation.

\section{Results and Discussion}

\subsection{Removal of Arsenic from Contaminated Water}

\subsubsection{Haix-Fe-Zr Resin Bead Performance}

This study shows that Haix-Fe-Zr resin beads which are loaded with HFOs and $\mathrm{HZrOs,}$ were effective in removing $\mathrm{As}(\mathrm{III})$ and $\mathrm{As}(\mathrm{V})$ from the arsenic spiked groundwater, with a greater and more rapid removal of $\mathrm{As}(\mathrm{V})$ compared to As(III). As reported by Salker et al. (2008), Haix-Fe resin beads, which are similar to the Haix-Fe-Zr resin beads, have a high affinity for arsenic due to a high surface area created by the HFOs, and the HFO's perform at a similar capacity to resin beads with granular ferric hydroxides $(\mathrm{GFH})$ for both As(III) and As(V). Additionally Salker et al (2008) stated that the Fe content of the Haix-Fe resin bead is much lower than the Fe content of GFH, nevertheless, Haix-Fe resin beads removes a similar amount arsenic. After 1 hour of shaking As(V) spiked groundwater with Haix-Fe-Zr resin beads, As(V) concentrations decreased from $215 \mu \mathrm{g} / \mathrm{L}$ to $33.88 \mu \mathrm{g} / \mathrm{L}$ (Figure 2a), resulting in an $84.24 \%$ removal of $\mathrm{As}(\mathrm{V})$ from the groundwater (Figure $2 \mathrm{~b}$ ).

Additionally, after 8 hours of shaking, the $\mathrm{As}(\mathrm{V})$ concentrations decreased to $6.37 \mu \mathrm{g} / \mathrm{L}$ which is below the WHO drinking water standards for arsenic at $10 \mu \mathrm{g} / \mathrm{L}$, resulting in a $97.04 \%$ As $(V)$ removed from the groundwater. After 1 week of shaking, As(V) concentrations decreased to $2.31 \mu \mathrm{g} / \mathrm{L}$ in the groundwater with a $98.92 \%$ removal of $\mathrm{As}(\mathrm{V})$. Concentrations 
of As(III) decreased from $219.8 \mu \mathrm{g} / \mathrm{L}$ to $41.42 \mu \mathrm{g} / \mathrm{L}$ with an $81.16 \%$ removal of As(III) from the groundwater, after 4 hours of shaking the As(III) spiked groundwater with Haix-Fe-Zr resin beads. After 24 hours and 1 week of shaking, As(III) concentrations decreased to $8.37 \mu \mathrm{g} / \mathrm{L}$ with a $96.19 \%$ removal of $\mathrm{As}(\mathrm{III})$, and $2.26 \mu \mathrm{g} / \mathrm{L}$ with a $98.97 \%$ removal of $\mathrm{As}(\mathrm{III})$ from groundwater, respectively.

\subsubsection{Haix-Zr Resin Bead Performance}

In this study, Haix-Zr resin beads were more effective in removing As(III) and As(V) from the spiked groundwater, compared to Haix-Fe-Zr resin beads. Additionally, Haix-Zr resin beads removed $\mathrm{As}(\mathrm{V})$ more rapidly compared to $\mathrm{As}(\mathrm{III})$. Concentrations of $\mathrm{As}(\mathrm{V})$ decreased from $185.8 \mu \mathrm{g} / \mathrm{L}$ to $45.27 \mu \mathrm{g} / \mathrm{L}$ (Figure $2 \mathrm{c}$ ), with a $75.64 \%$ removal of As(V) from the spiked groundwater after 10 minutes of shaking (Figure 2d). Concentrations of As(V) continued to decrease to $8.79 \mu \mathrm{g} / \mathrm{L}$, where $95.27 \%$ of $\mathrm{As}(\mathrm{V})$ was removed after 4 hours of shaking. After 1 week of shaking, As(V) concentrations decreased to $0.612 \mu \mathrm{g} / \mathrm{L}$ and $99.67 \%$ $\mathrm{As}(\mathrm{V})$ was removed from the spiked groundwater. As(III) concentrations decreased from $187.2 \mu \mathrm{g} / \mathrm{L}$ to $31.11 \mu \mathrm{g} / \mathrm{L}$, where $83.38 \% \mathrm{As}(\mathrm{III})$ was removed from the groundwater after 1 hour of shaking. Concentrations of As(III) decreased to $7.72 \mu \mathrm{g} / \mathrm{L}$ where $95.88 \%$ of As(III) was removed from the groundwater after 8 hours of shaking. After 1 week of shaking, As(III) concentrations decreased to $1.1 \mu \mathrm{g} / \mathrm{L}$ with a $99.41 \%$ removal of As(III) from the spiked groundwater.

Other groundwater treatment systems have been set-up to treat As(III) using oxidative and filtration methods where $\mathrm{Fe}_{2} \mathrm{O}_{3}$ is used as a filter (Nieto-Delgado and Rangel-Mendez, 2012) and $\mathrm{As}(\mathrm{III})$ is oxidized by $\mathrm{OCl}^{-}$and $\mathrm{Fe}$ precipitation (Meng et al, 2001) where $>98 \%$ and $>95 \%$ As(III), respectively, were removed from the water (Jiang et al., 2013). Field and household trials were also carried-out on these techniques which showed promise and a cost 
saving methods for removing As from drinking water; however, the Haix resin beads still out performed these methods (Sarkar et al, 2008). Adsorption treatments using iron based sorbents (van Geen, et al., 2003) and layered double hydroxides (LDH) (Grover et al., 2009) are also reported to remove up to $98 \%$ As and $96 \%(\mathrm{AsV})$, respectively, from groundwater (Jiang et al., 2013).

\subsection{Removal of Fluoride from Contaminated Water}

\subsubsection{Haix-Fe-Zr Resin Bead Performance}

The groundwater from the sampling site in Northern Ireland had $1.27 \mathrm{mg} / \mathrm{L}$ naturally occurring $\mathrm{F}^{-}$. The groundwater sample was further spiked with $5 \mathrm{mg} / \mathrm{L} \mathrm{F}^{-}$resulting in a concentration of $6.27 \mathrm{mg} / \mathrm{L}$. Although according to Padungthon et al (2014) HAIX-Zr resin beads are designed to treat $\mathrm{F}^{-}$containing groundwater, this current study shows that Haix-Fe$\mathrm{Zr}$ resin beads were more effective in removing $\mathrm{F}^{-}$, compared to Haix- $\mathrm{Zr}$ resin beads, in the groundwater conditions similar to the study site in West Bengal, India (Mukhopadhyay et al., submitted). This could be due to the presence of $\mathrm{HZrO}$ in these resin beads. Regardless of this comparison, this study also revealed that both Haix-Fe- $\mathrm{Zr}$ and Haix- $\mathrm{Zr}$ resin beads were effective in removing $\mathrm{F}^{-}$from the groundwater. After 15 minutes of shaking the spiked groundwater with Haix-Fe-Zr resin beads, $\mathrm{F}^{-}$concentrations decreased from $6.27 \mathrm{mg} / \mathrm{L}$ to $1.27 \mathrm{mg} / \mathrm{L}$ (Figure 3a), which is below the WHO drinking water guideline limits for $\mathrm{F}^{-}$of 1.5mg/L. After 15 minutes of shaking the spiked groundwater with Haix-Fe-Zr resin beads, there was a $79.82 \%$ removal of $\mathrm{F}^{-}$, and almost complete removal of $\mathrm{F}^{-}$at $99.75 \%$ was achieved after 2 hours of shaking (Figure $3 b$ ).

\subsubsection{Haix-Zr Resin Bead Performance}

In this study, concentrations of $\mathrm{F}^{-}$in the spiked groundwater decreased from $6.27 \mathrm{mg} / \mathrm{L}$ to $1.425 \mathrm{mg} / \mathrm{L}$ after 20 minutes of shaking with Haix-Zr resin beads (Figure 3a) where $77.27 \%$ 
$1 \quad \mathrm{~F}^{-}$was removed (Figure $3 \mathrm{~b}$ ). After 2 hours of shaking the groundwater with Haix-Zr resin

2 beads, $\mathrm{F}^{-}$concentrations decreased to $0.58 \mathrm{mg} / \mathrm{L}$ with a $90.77 \%$ removal. Fluoride continued

3 to decrease in concentration over time to $0.26 \mathrm{mg} / \mathrm{L}$ with a $95.87 \%$ removal after 24 hours of

4 shaking.

The main issues with adsorbents that remove fluoride, as well as arsenic and other

6 contaminants from water, are the lack of robustness and the inability to undergo multiple

7 regeneration cycles. The Haix resin beads have been proven in the field to robust and

8 regeneratable (SenGupta, 2017). Other adsorbents reported to be effective in removing

9 fluoride from drinking water are rare earth oxide based materials, clays, biosorbents, waste materials, however, they have either been proven expensive, show poor regeneration, leach toxic metals or fail in field tests (Bhatnagar et al. 2011). Activated alumina adsorption (AAA) is an established technology in the removal of fluoride, and it is considered by WHO and USEPA as one of the best demonstrated available technology (BDAT) as it is a robust adsorbent for removing fluoride from drinking water. Nevertheless, AAA is expensive, has a sensitive $\mathrm{pH}$ dependent adsorption capacity, and co-ions (i.e. sulphates, bicarbonates, silicates, chlorides, and phosphates) in water hinder its performance (Tressaud, 2006; Bhatnagar et al. 2011). Additionally, extra care and attention is needed when using aluminium-based sorbents for removing fluoride from water as aluminium is a neurotoxin and could endanger human health (Bhatnagar et al. 2011), which is not an issue with the Haix resin beads.

\subsection{Kinetic Modeling}

\subsubsection{Arsenic}


The kinetic data were modeled using the rate reaction equations and the PDE to evaluate the adsorption mechanism of the contaminants onto the Haix $\mathrm{Fe}-\mathrm{Zr}$ and Haix- $\mathrm{Zr}$ (Table 1). The $\mathrm{R}^{2}$ values obtained from the equations were generally higher for the PDE followed by the first order equation for the arsenic spiked groundwater treated with Haix-Fe$\mathrm{Zr}$ and Haix-Zr resin beads (Table 1; Figure 4a-d). However, the $\mathrm{R}^{2}$ value for As(III) spiked groundwater was slightly lower for the PDE compared to the first order equation, nevertheless, the SE was noticeably lower for the PDE, compared to the first order equation, making the PDE a better fitting model in this study. The PDE model is widely used to describe diffusion-controlled phenomena and the release of ions (Havlin et al. 1985, Hodges and Johnson 1987). In the current study, the adsorption of As(III) and As(V) onto resin beads may be controlled by the film diffusion at earlier stages and then, as the adsorbent particles are loaded with the pollutant ions, the adsorption process may then be controlled by the intraparticle diffusion. The $\mathrm{k}$ value can be obtained from the slope of the plot $\mathrm{C} / \mathrm{C}_{\max } \mathrm{vs} \mathrm{t}^{1 / 2}$. According to Vadivelan and Kumar (2005) and Weng and Pan (2006), strong correlation to PDE suggests that the adsorption process proceeds by surface adsorption followed by intraparticle diffusion. Calculated values of intra-particle diffusion coefficient, (or Reaction Rate $\mathrm{k}$ ), given in Table 1, increase with the increase in the adsorption. This is attributed to the instantaneous utilization of the most readily available adsorption sites on the resin surfaces.

The better fit with the PDE model, compared to the other kinetic models in this study, is supported by the macro-porous morphology of the resin beads which allows for the contaminated groundwater to move through the beads and the distribution of the nano-sized HFO and $\mathrm{HZrO}$ particles on and within the beads which adsorb the contaminant. Microscopic study of Haix-Fe-Zr resin beads which were shaken in As(V) spiked groundwater revealed that as As spiked groundwater flows through the nano-pores in resin beads (Figure 1b), the As is sorbed uniformally to the surface and within the beads as shown 
1 in the SEM elemental maps of the beads (Figures 6a-d and 7a-c), especially where the HZrO

2 nano-precipitates are present compared to the HFO nano-precipitates (Figure 6c) which occur

3 in more concentric orientation. Smith et al (2015) reports in the instances when anion

4 exchange resin beads are used as host materials for HFOs and $\mathrm{HZrO}$ anions in the

5 groundwater such as $\mathrm{F}^{-}, \mathrm{As}(\mathrm{V}), \mathrm{SO}_{4}{ }^{2-}, \mathrm{Cl}^{-}$, and $\mathrm{PO}_{4}{ }^{2-}$ are increasingly drawn inside the bead

6 allowing sorption onto the HFO and $\mathrm{HZrO}$ nanoparticles. In the current study, the polished

7 sections of Haix-Zr resin beads shaken with $\mathrm{As}(\mathrm{V})$ spiked groundwater also showed arsenic

8 along with $\mathrm{Si}, \mathrm{S}$ and Ca sorbed onto the surface and within the beads (Supporting

9 Information-Figure 1s). Padungthon et al. (2015) report significant competition between As

10 and $>30 \mathrm{mg} / \mathrm{L} \mathrm{SiO}_{2},>250 \mathrm{mg} / \mathrm{L} \mathrm{PO}_{4}{ }^{2-},>200 \mathrm{mg} / \mathrm{L} \mathrm{SO}_{4}{ }^{2-}$ on HAIX-Zr resin beads in natural 11 groundwater.

\subsubsection{Fluoride}

In this study, the first order equation shows higher $\mathrm{R}^{2}$ values compared to the PDE for fluoride, however, the SE values for the first order equation were notably higher (Table 1; Figure 5a-d). Therefore, the best model of pollutant desorption from the resin beads was PDE followed by the first order equation. Similar to As, the adsorption of $\mathrm{F}^{-}$onto resin particles may be controlled by film diffusion at earlier stages and as the adsorbent particles are loaded with pollutant ions, the adsorption process may become controlled by intraparticle diffusion.

Microscopic analysis also supports the PDE model in the adsorption of $\mathrm{F}^{-}$onto the resin beads in this study. SEM analysis of polished sections of Haix-Fe-Zr resin beads that treated the $\mathrm{F}^{-}$spiked ground water show $\mathrm{F}^{-}$associated with the nanoparticles of HFOs and $\mathrm{HZrOs}$ on and within the resin beads, especially $\mathrm{HZrO}$ nano-precipitates where $\mathrm{F}$ sorption has resulting in highlighting their presence (Figures 6e-h and 7d-f). Sodium, sulfur, calcium, and 
1 chloride were also adsorbed onto and within the Haix-Fe-Zr resin beads (Supporting

2 Information-Figure 1s) indicating that these elements could compete for exchange sites with

3 the $\mathrm{F}^{-}$on the Haix-Fe-Zr resin beads under these groundwater conditions. Sodium is possibly

4 introduced from $\mathrm{NaF}$ being used to spike the groundwater in this study. Padungthon et al.

5 (2014) report no compete effects of $\mathrm{SO}_{4}{ }^{2-}$ or $\mathrm{Cl}^{-}$due to low electrostatic interaction in the

6 removal of $\mathrm{F}^{-}$by HAIX-Zr resin beads. The quaternary ammonium functional groups $\left(\mathrm{R}_{4} \mathrm{~N}^{+}\right)$

7 in HAIX increase the accessibility of $\mathrm{F}^{-}$to nanoparticles of $\mathrm{HZrO}$ embedded within the gel

8 phase. The sorption of $\mathrm{F}^{-}$onto HAIX- $\mathrm{Zr}$ resin beads is $\mathrm{pH}$ dependent (Padungthon et al.,

9 2014). Nevertheless, SEM analysis of polished sections of the Haix-Zr resin beads in this

10 study reveals $\mathrm{Na}^{+}$along with $\mathrm{F}^{-}$adsorbed onto the beads (Supporting Information-Figure 2s).

$11 \mathrm{The}^{+}{ }^{+}$from the $\mathrm{NaF}$ sorbed onto the resin beads revealing the $\mathrm{Na}^{+}$could be a competing ion for exchange site on the resin beads under these neutral $\mathrm{pH}$ groundwater conditions.

\section{Conclusions}

This kinetic study examined the effectiveness of Haix-Fe- $\mathrm{Zr}$ and Haix- $\mathrm{Zr}$ anion exchange resin beads in removing As and $\mathrm{F}^{-}$from the contaminated groundwater below the WHO guideline values. Haix-Zr resin beads were more effective than Haix-Fe-Zr resin beads in removing $\mathrm{As}(\mathrm{III})$ and $\mathrm{As}(\mathrm{V})$. Haix-Zr resin beads showed the greater removal of $\mathrm{As}(\mathrm{V})$ compared to As(III). Haix- $\mathrm{Zr}$ resin beads reduced $\mathrm{As}(\mathrm{V})$ to $45.27 \mu \mathrm{g} / \mathrm{L}$ after 10 minutes of shaking and below the WHO $(10 \mu \mathrm{g} / \mathrm{L})$ drinking water standards at $8.79 \mu \mathrm{g} / \mathrm{L}$ after 4 hours of shaking, while As(III) was reduced to $31.11 \mu \mathrm{g} / \mathrm{L}$ and $7.72 \mu \mathrm{g} / \mathrm{L}$ after 1 hour and 8 hours after shaking, respectively. Concentrations of $\mathrm{As}(\mathrm{III})$ and $\mathrm{As}(\mathrm{V})$ decreased to $33.88 \mu \mathrm{g} / \mathrm{L}$ and $41.42 \mu \mathrm{g} / \mathrm{L}$, respectively, after 1 hour of shaking the spiked groundwater in Haix-Fe-Zr resin beads. Haix-Fe-Zr resin beads were more effective in removing $\mathrm{F}^{-}$from the spiked groundwater compared to Haix-Zr resin beads. Concentrations of $\mathrm{F}^{-}$decreased from 
$16.27 \mathrm{mg} / \mathrm{L}$ to $1.26 \mathrm{mg} / \mathrm{L}$, which is below the WHO drinking water standards $(1.5 \mathrm{mg} / \mathrm{L})$ for $\mathrm{F}^{-}$

2 after 15 minutes of shaking with Haix-Fe-Zr resin beads. After 20 minutes of shaking in

3 Haix-Zr resin beads, $\mathrm{F}^{-}$concentrations decreased from $6.27 \mathrm{mg} / \mathrm{L}$ to $1.43 \mathrm{mg} / \mathrm{L}$. Haix-Fe- $\mathrm{Zr}$

4 and Haix-Zr resin beads best fit the PDE suggesting that adsorption of As and $\mathrm{F}^{-}$were

5 consistent with inter-particle diffusion.

6

7

8

\section{Acknowledgements}

This research project was supported by Global Innovation Initiative (US Department of State) and Scientific Event Limited (UK) Limited.

\section{References}

Aredes, S., Klein, B., Pawlik, M., 2013. The removal of arsenic from water using natural iron oxide minerals. J. Clean. Prod. 60, 71-76.

Bagla, P., Kaiser, J., 1996. India's spreading health crisis draws global arsenic experts. Science. 274, 174-175.

Bang, S., Patel, P., Lippincott, L., Meng, X., 2005. Removal of arsenic from groundwater by granular titanium dioxide adsorbent. Chemosphere. 60(3), 389-97

Bearak, D. 1998. New Bangladesh disaster: Wells that pump poison. The New York Times, New York, USA.

Berg, M., Stengel, C., Trang, P.T., Viet, P.H., Sampson, M.L., Leng, M., Samreth, S., Fredericks, D., 2007. Magnitude of arsenic pollution in the Mekong and Red River deltasCambodia and Vietnam. Sci. Tot. Environ. 372(2-3), 413-425.

Bhatnagar, A., Kumar, E., Sillanpaa, M., 2011. Fluoride removal from water by adsorptionA review. Chem. Engineer. J. 171, 811-840.

Bhattacharya, P., Welch, A.H., Stollenwerk, K.G., McLaughlin, M.J., Bundschuh, J., Panaullah, G., 2007. Arsenic in the environment: biology and chemistry. Sci. Tot. Environ. 379(2-3), 109-120.

Bureau of Indian Standards, IS 10500 (2012): Drinking Water (FAD 25: Drinking Water), Manak Bhavan, 9 Bahadur Shah Zafar Marg New Delhi 110002, pp16.

Bundschuh, J., Litter, M., Parvez, F., Román-Ross, G., Nicolli, H.B., Jean, J-S., Liu, C-W., López, D. Armienta, M.A., Guilherme, L.R.G., Gomez-Cuevas, A., Cornejo, L., Cum- 
bal, L., Toujaguez, R., 2012. One century of arsenic exposure in Latin America: A review of history and occurrence from 14 countries. Sci. Tot. Environ. 429, 2-35.

Dutta, P.K., Ray, A.K., Sharma, V.K., Millero, F.J., 2004. Adsorption of arsenate and arsenite on titanium dioxide suspensions. J. Colloid Interface Sci. 278(2), 270-275.

Environmental Protection Agency., 2001. Technical fact sheet: Final rule for arsenic in drinking water. EPA 815-F-00-016.

Havlin, J. L., Westfall, D.G., Olsen, R.S., 1985. Mathematical models for potassium release kinetics in calcareous soils. Soil Sci. Soc. Am. J. 49, 366-370.

Hodges, S.C., Johnson, G.C., 1987. Kinetics of sulfate adsorption and desorption by Cecil soil using miscible displacement. Soil Sc. Soc. Am. J. 51(2), 323-331.

Grover, K., Komarneni, S., Katsuki, H. 2009., Uptake of arsenite by synthetic double hydroxides. Water Res. 43, 3884-3890.

Jacks, G., Bhattacharya, P., Chaudhary,V., Singh, K.P., 2005. Controls on the genesis of some high-fluoride groundwaters in India. Appl. Geochem. 20, 221-228.

Jaglan, M.S., Qureshi, M.H., 1996. Irrigation development and its environmental consequences in arid regions of India. Environ. Manage. 20. 323-336.

Jiang, J.-Q., Ashekuzzaman, S.M., Anlun J., Sharifuzzaman, S.M., Chowdhury, S.R., 2013. Arsenic contaminated groundwater anf its treatment options in Bangladesh. Int. J. Environ. Res Public Health 10, 18-46.

Krishnamachari, K.A.V.R. 1976. Further observations on the syndrome of endemic genu valgum of South India. Indian J. Med. Res. 64, 284-292.

Meng, X., Korfiatis, G.P., Christodoulatos, C., Bang, S. 2001., Treatment of arsenic in Bangladesh well water using a household co-precipitation and filtration system. Water Res. $35,2805-2810$.

Mukhopadhyay, S., Mukherjee, S., Sen Gupta, B., Phillips, D.H., Bandopadhyay, A., Sen Gupta, A.K., (Submitted). Enhancing the capacity of a community arsenic treatment plant using a two stage treatment process. Process Safety Environ. Protect.

Nieto-Delgado, C., Rangel-Mendez, J.R., 2012. Anchorage of iron hydro(oxide)

nanoparticles onto activated carbon to remove As(V) from water. Water Res. 46, 2973-2982.

Padungthon, S., Li, J., German, M., SenGupta, A.K., 2014. Hybrid anion exchanger with dispersed zirconium oxide nanoparticles: a durable and reusable fluoride-selective sorbent. Environ. Engineer. Sci. 31(7), 360-372.

Padungthon, S., German, M., Wiriyathamcharoen, S., SenGupta, A.K., 2015. Polymeric anion exchanger supported hydrated $\mathrm{Zr}$ (IV) oxide nanoparticles: a reusable hybrid sorbent for selective trace arsenic removal. Reactive Functional Polymers 93, 84-94 
Raj, A.J., Umayorubhagan, V., 2013. Fluorosis in relation to nutrition, fluoride in drinking water and socio economic background in Agastheswaram Union, India, IJIET, 2, 337-339.

Ramana, A., Sengupta, A.K., 1992. Removing selenium (IV) and arsenic (V) oxyanions with tailored chelating polymers. J. Environ. Engineer. 118(5), 755-775

Ravenscroft, P., Burgess, W.G., Ahmed, K.M., Burren, M., Perrin, J., 2005. Arsenic in groundwater of the Bengal Basin, Bangladesh: distribution, field relations, and hydrogeological setting. Earth Environ. Sci. 13(5-6), 727-751.

Sarkar, S., Blaney, L.M., Gupta, A., Ghosh, D., SenGupta, A.K., 2008. Arsenic removal from groundwater and its safe containment in a rural environment: Validation of a sustainable approach. Environ. Sci. Technol. 42(12), 4268-73.

SenGupta, A.K., 2017. Ion Exchange in Environmental Processes: Fundamentals, Applications and Sustainable Techology, John Wiley and Sons, Inc. Pp. 496.

SenGupta, A.K., Cumbal, L.H., inventors; SenGupta AK, assignee. 2007. Hybrid anion exchanger for selective removal of contaminating ligands from fluids and method of manufacture thereof. U.S. patent US 7291578, Nov 6.

Sen Gupta, B., Chatterjee, S., Rott, U., Kauffman, H., Bandopadhyay, A., 2009. A simple chemical free arsenic removal method for community water supply-A case study from West Bengal, India.cEnviron. pollution. 157(12), 3351-3353

Smith, R.C., Li, J., Padungthon, S., Sengupta, A.K., 2015. Nexus between polymer support and metal oxide nanoparticles in hybrid nanosorbent materials (HNMs) for sorption/desorption of target ligands. Frontiers Environ. Sci. Engineer. 9 (5), 929-938.

Stanger, G., Truong, T.V., Ngoc, K.S., Luyen, T.V., Thanh, T.T., 2005. Arsenic in groundwaters of the lower Mekong. Environ. Geochem. Health. 27(4), 341-57.

Suzuki, T.M., Bomani, J.O., Matsunaga, H., Yokoyama, Y., 2000. Preparation of porous resin loaded with crystalline hydrous zirconium oxide and its application to removal of arsenic. React. Funct. Polym. 43(1-2), 165-167

Tressaud, A., (Ed.), Advances in Fluorine Science, Fluorine and the Environment, Agrochemicals, Archaeology, Green Chemistry \& Water, vol. 2, Elsevier, 2006.

Vadivelan, V., Kumar, K.V., 2005. Equilibrium, kinetics, mechanism, and process design for the sorption of methylene blue onto rice husk. J. Colloid Interface Sci. 286(1), 90-100.

van Geen, A., Zheng, Y.,Versteeg, R., Stute, M., Horneman, A., Dhar, R., Steckler, M., Gelman, A., Small, C., Ahsan, H., Graziano, J.H., Hussain, I., Ahmed, K.M., 2003. Spatial variability of arsenic in 6,000 tube wells in a $25 \mathrm{~km}^{2}$ area of Bangladesh. Water Resour. Res. 39,1140 .

World Health Organisation (WHO), 2011, Arsenic in Drinking-water. Background document for development of WHO Guidelines for Drinking-water Quality WHO/SDE/WSH/03.04/75 
2

3

4

5

6

7

8

9

10

11

12

13

/Rev/1 WHO Press, World Health Organization, 20 Avenue Appia, 1211 Geneva 27, Switzerland, pp16.

\section{List of Figures}

Figure 1. a) Photomicrograph of a polished cross-section of Haix-Fe-Zr resin beads showing the internal concentric and irregular patterns of orange to dark reddish $\mathrm{HFO}$ and $\mathrm{HZrO}$ precipitates; b) TEM micrographs of a Haix-Fe-Zr resin bead showing the external and internal distribution of the nano-sized HFO and $\mathrm{HZrO}$ precipitates and nano-sized pores/voids throughout the resin bead (HFO precipitates are acicular in shape); c) Photomicrograph of a polished section of Haix- $\mathrm{Zr}$ resin beads showing the internal beige to white colour; and d) TEM micrographs of a Haix-Zr bead showing the external and internal distribution of the nano-sized $\mathrm{HZrO}$ precipitates and nano-sized pores/voids throughout the resin bead.

Figure 2. a) Reduction and b) removal rates of $\mathrm{As}(\mathrm{III})$ and $\mathrm{As}(\mathrm{V})$ concentrations over time in spiked groundwater treated with Haix-Fe-Zr resin beads. c) Reduction and d) removal rates of As(III) and As(V) concentrations over time in spiked groundwater treated with Haix-Zr resin beads.

Figure 3. a) Reduction and b) removal rates of fluoride concentrations over time in spiked groundwater treated with Haix-Fe-Zr and Haix-Zr resin beads.

Figure 4. Kinetic data fitting for $\mathrm{As}(\mathrm{III})$ and $\mathrm{As}(\mathrm{V})$ in a) Zero order; b) First order; c) Second order; and d) Parabolic Diffusion Equation,

Figure 5. Kinetic data fitting for fluoride in a) Zero order; (b) First order; c) Second order; and d) Parabolic Diffusion Equation.

Figure 6. SEM-BSE photomicrographs and elemental maps of Haix-Fe-Zr resin beads used to remove As and fluoride from spiked groundwater. a) SEM-BSE photomicrograph of a crosssection of Haix-Fe-Zr resin beads collected from $\mathrm{As}(\mathrm{V})$ spiked groundwater showing the concentric formations of HFO and HZrO precipitates and void spaces within the resin beads. Elemental maps of the distribution of b) $\mathrm{Zr}$, c) Fe and d) As in the Haix-Fe-Zr resin beads in (a). e) SEM-BSE photomicrograph of a cross-section of Haix-Fe-Zr resin beads collected from fluoride spiked batch reactors showing the concentric formations of $\mathrm{HFO}$ and $\mathrm{HZrO}$ precipitates and void spaces within the resin beads. Elemental maps of the distribution of $\mathrm{f}$ ) $\mathrm{Zr}$, g) Fe, and h) F in the Haix-Fe-Zr resin beads in (e).

Figure 7. SEM-BSE photomicrographs and elemental maps of Haix-Zr resin beads used to remove As and fluoride from spiked groundwater. a) SEM-BSE photomicrograph of a crosssection of resin beads used to remove As from groundwater. Elemental maps of the distribution of b) $\mathrm{Zr}$ and c) As in the Haix-Zr resin beads in (a). d) SEM-BSE photomicrograph showing $\mathrm{Zr}$ nano-precipitates in a cross-section of resin beads used to 
1 remove $\mathrm{F}$ from groundwater. Elemental maps of the distribution of e) $\mathrm{Zr}$ and $\mathrm{f}$ ) $\mathrm{F}$ in the 2 Haix-Zr resin beads in (a). 
$-1$

as $(\theta-\operatorname{cog}(*) r(x)$ 1
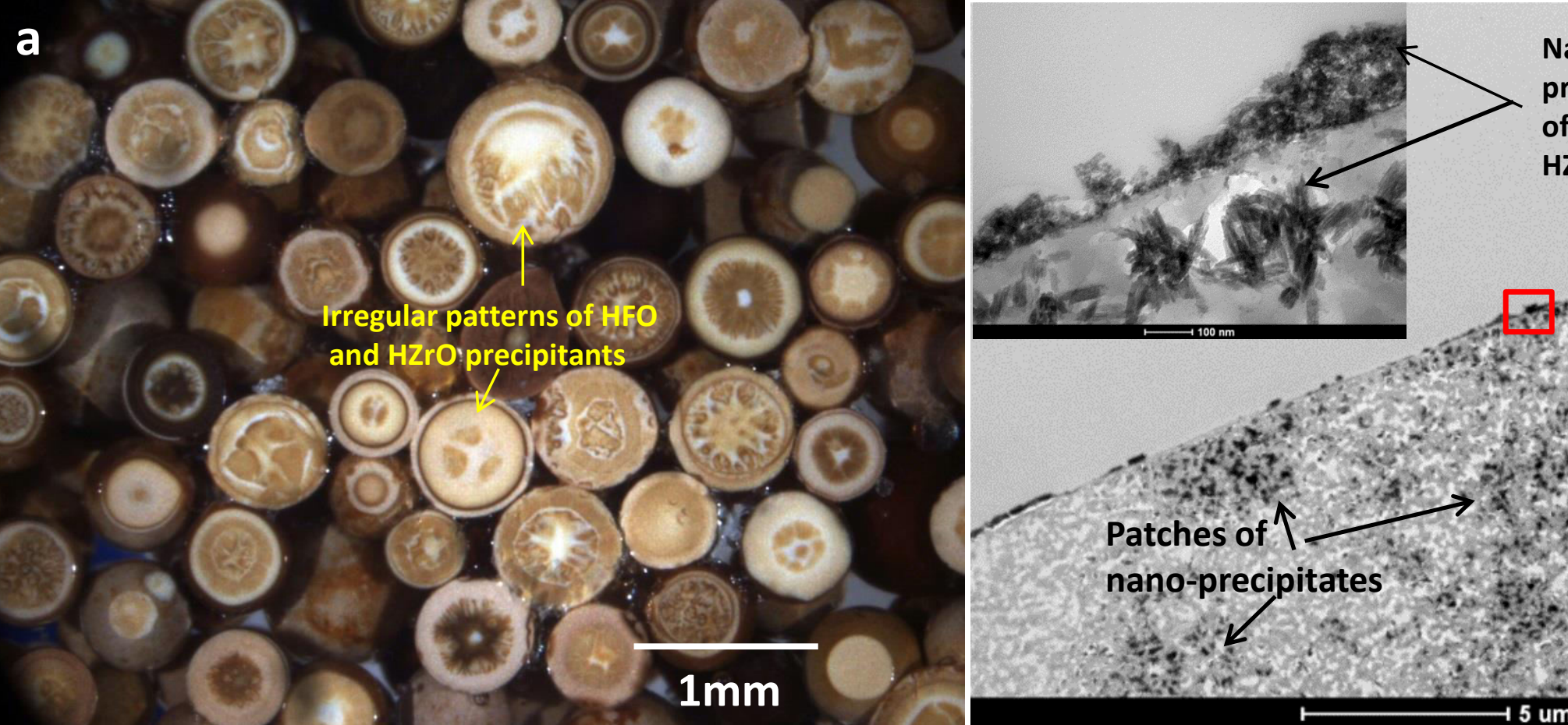

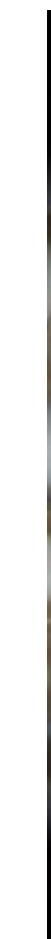

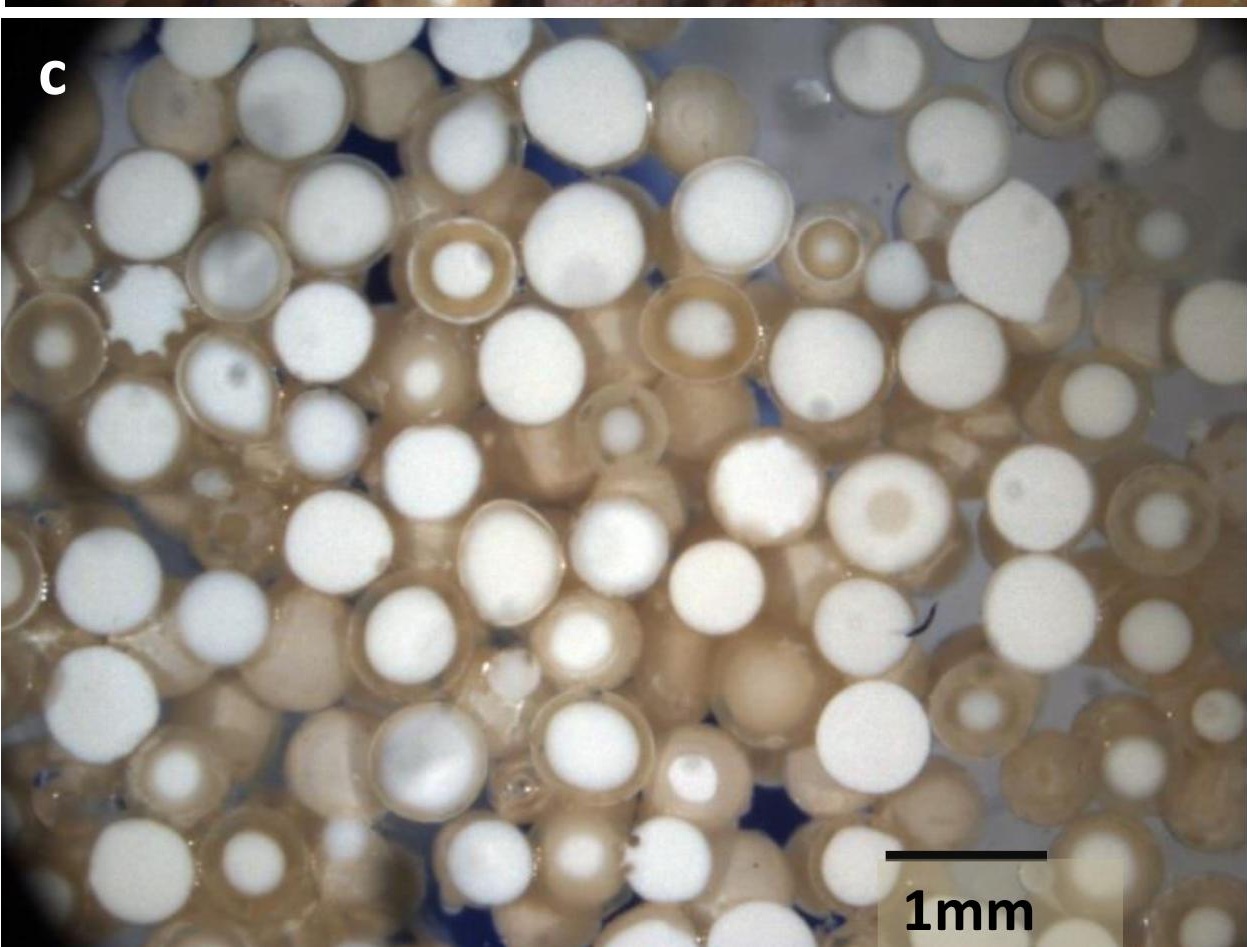

Nano-

precipitates of HFO and

HZrO
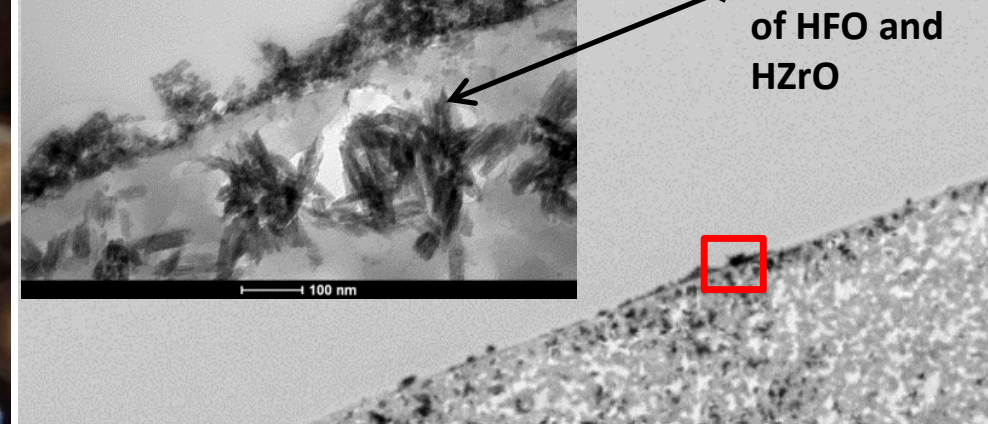

Nanoporous $-4 n+x^{2}$ Patches of $\uparrow$ nano-precipitates

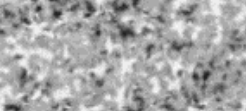
- matrix
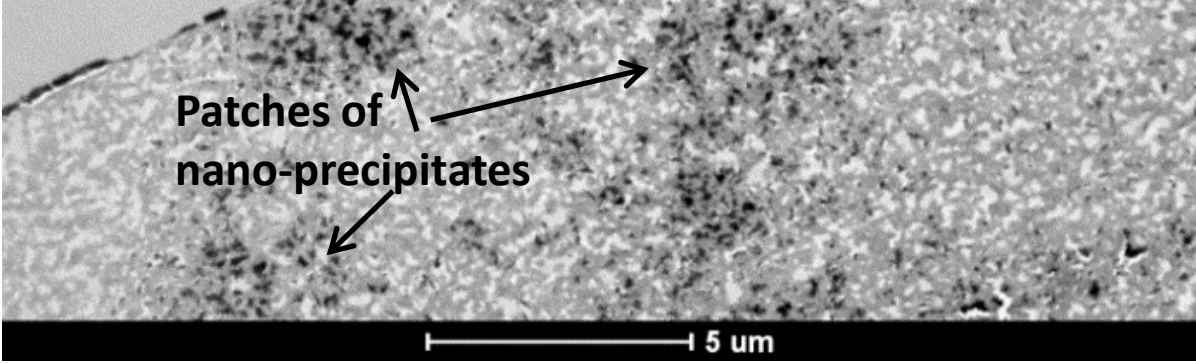

d

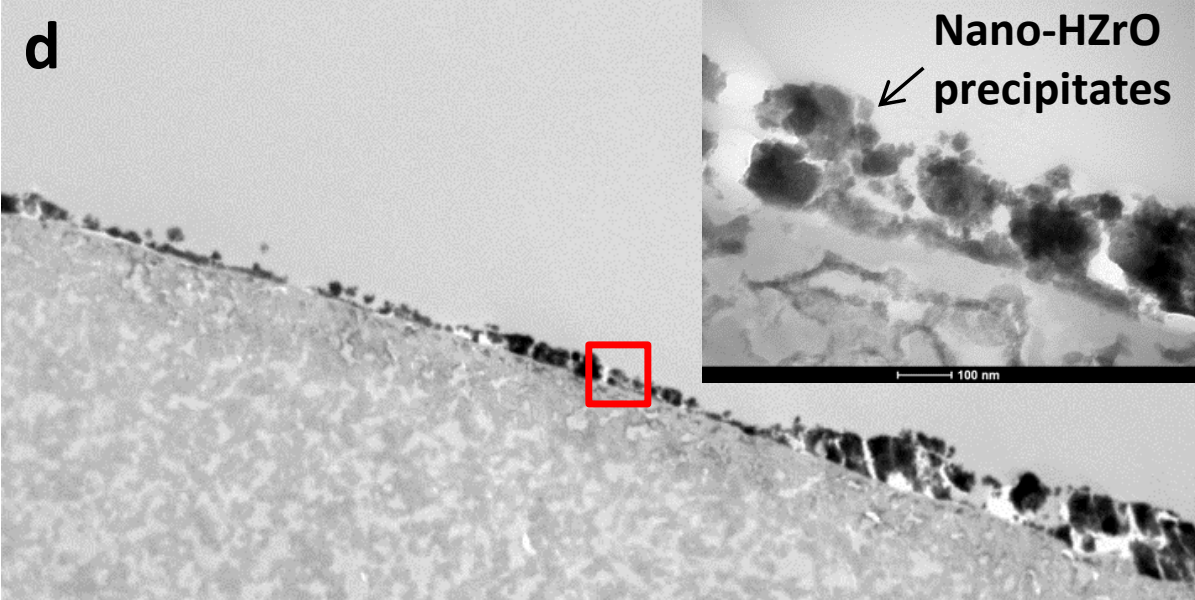


Figure 3

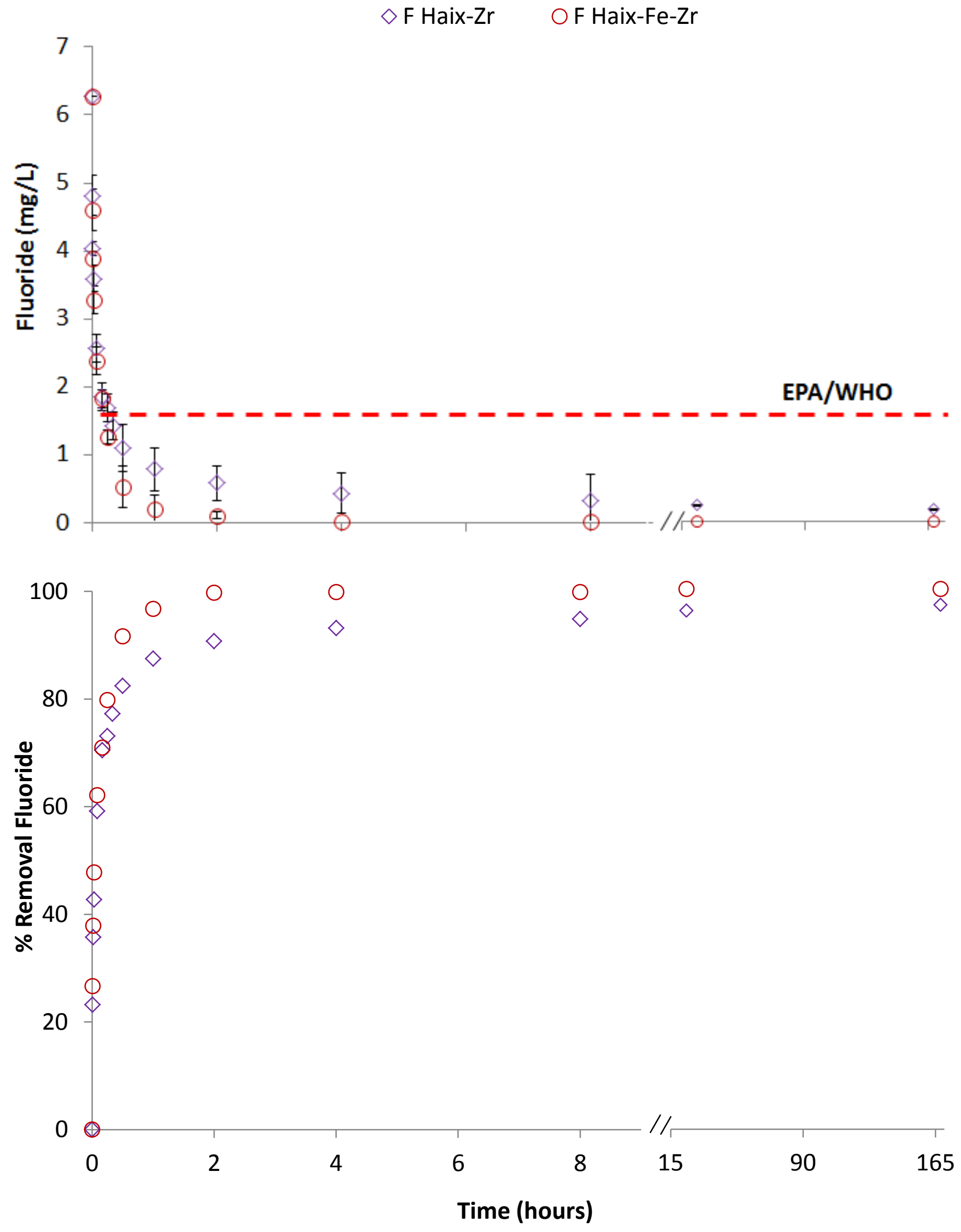



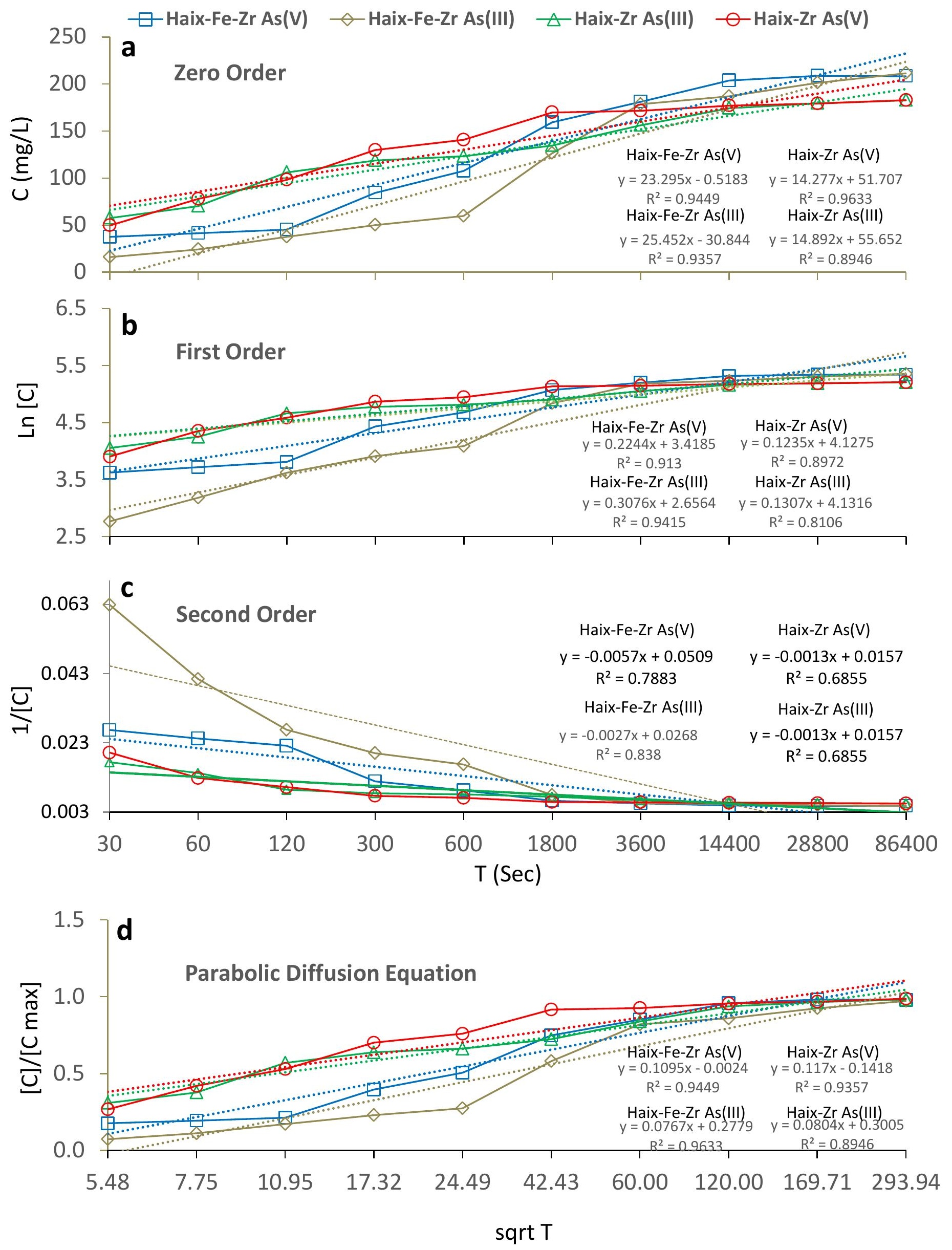

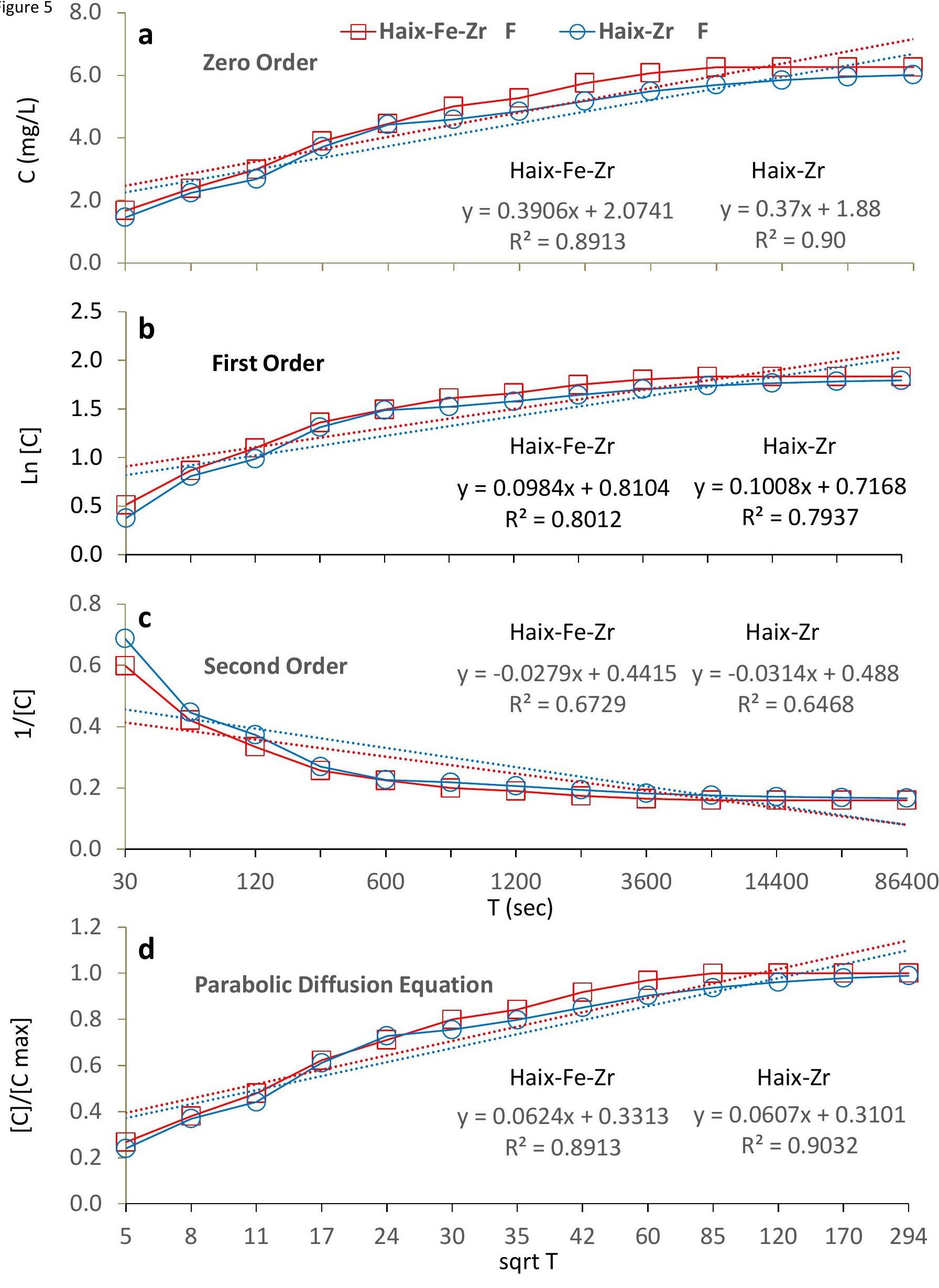
Figure 6
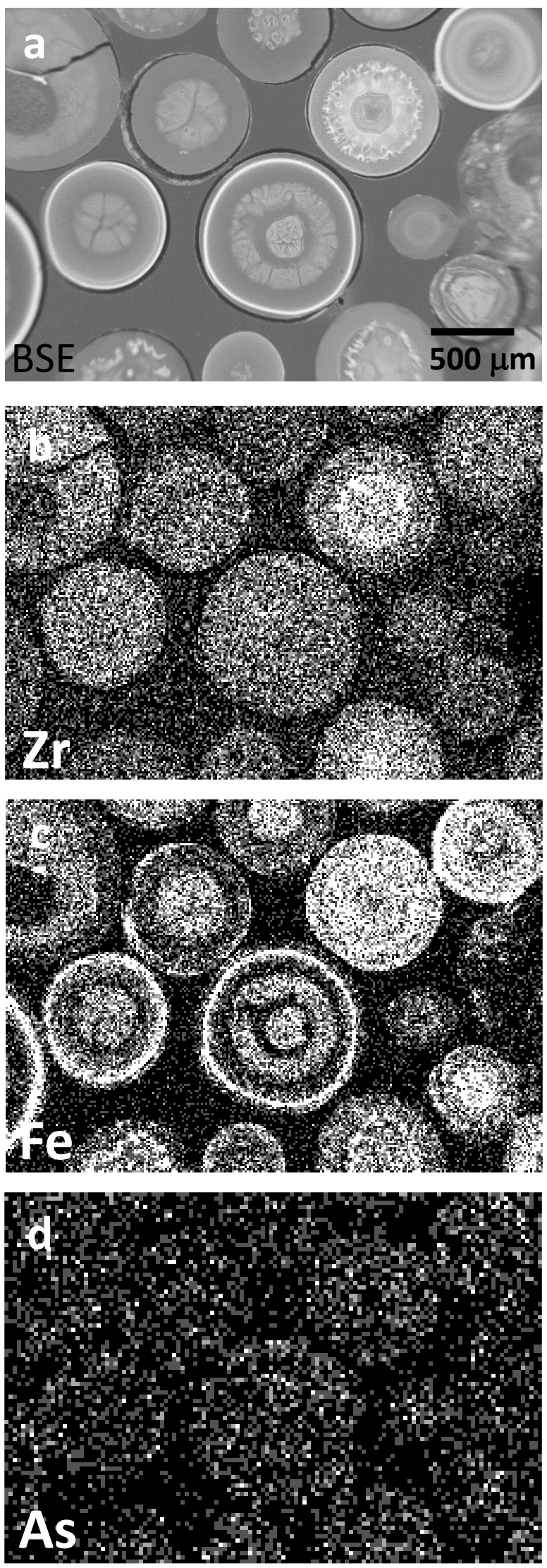
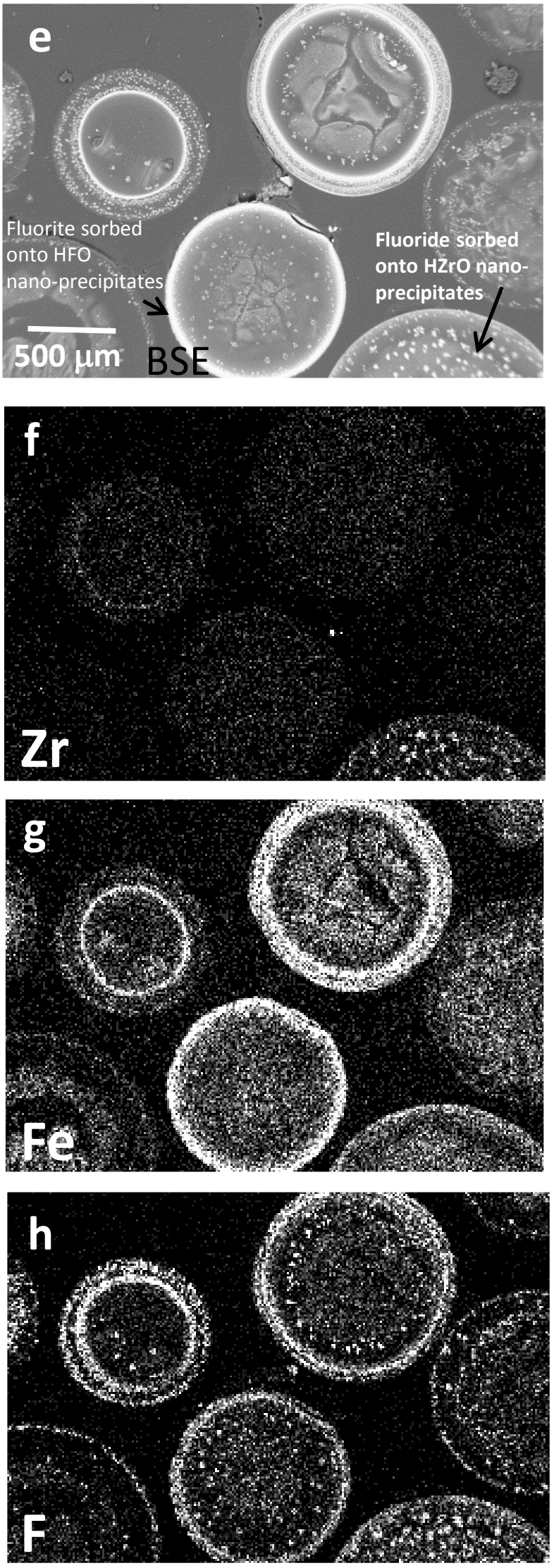


\section{Figure 7}

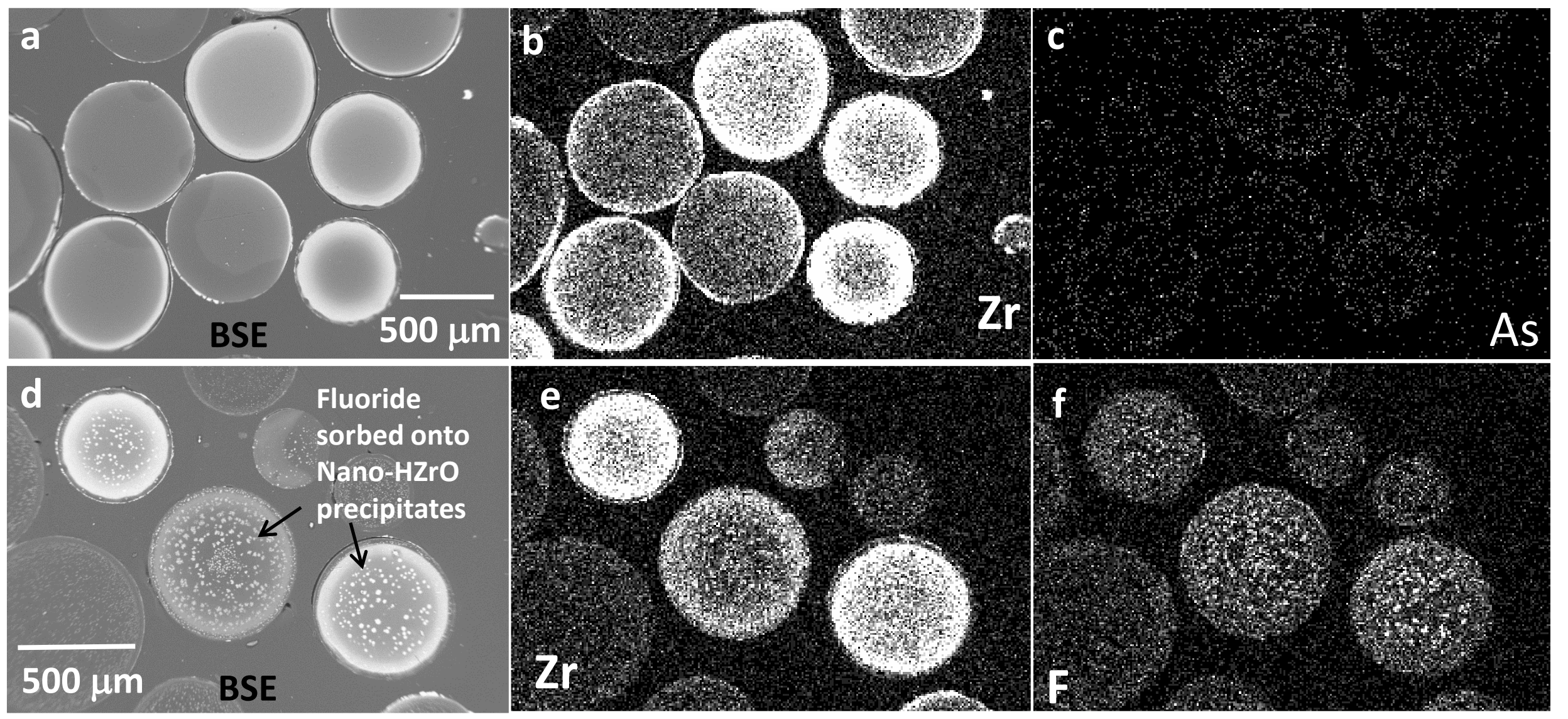


Table 1: Correlation coefficients $\mathrm{R}^{2}$ and standard error (SE) of kinetic models for (a) arsenic and (b) fluoride

\begin{tabular}{|c|c|c|c|c|c|c|c|c|c|c|c|c|c|c|c|c|}
\hline \multirow[b]{2}{*}{ Resin Bead } & \multicolumn{4}{|c|}{ Zero Order } & \multicolumn{4}{|c|}{ First Order } & \multicolumn{4}{|c|}{ Second Order } & \multicolumn{4}{|c|}{ Parabolic Diffusion Equation } \\
\hline & Slope & Const & $\mathrm{R}^{2}$ & SE & Slope & Const & $\mathrm{R}^{2}$ & SE & lope & Const & $\mathrm{R}^{2}$ & SE & Slope & Const & $\mathrm{R}^{2}$ & SE \\
\hline Haix-Fe-Zr $\mathrm{As}^{3+}$ & 25.452 & -30.844 & Iנכ & 16 & 0.3076 & 2.6564 & 0.9415 & 0.3035 & -0.0057 & 0.0509 & 0.7883 & 0.0061 & 0.117 & -0.1418 & 0.9357 & 0.1158 \\
\hline Haix-Fe-Zr $\quad \mathrm{As}^{5+}$ & .295 & 5183 & 9449 & .9438 & 2244 & 4185 & 913 & 0.2248 & -0.0027 & 0.0268 & 0.838 & 0.0028 & .1095 & -0.0024 & .9449 & 0.1079 \\
\hline$-\mathrm{Fe}-\mathrm{Zr} \quad \mathrm{F}^{-}$ & & & & & & & & & & 8 & 38 & 7 & 0.0624 & 3 & & 0714 \\
\hline Haix-Zr $\mathrm{As}^{3+}$ & 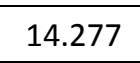 & & 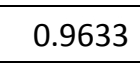 & 210 & כת & 75 & 0.8972 & 0.1248 & -0.0012 & 0.0153 & .7914 & .0013 & 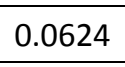 & 0.3313 & 8913 & 0.0714 \\
\hline Haix-Zr $\quad \mathrm{As}^{5+}$ & .892 & 5.652 & 8946 & 5.0746 & 0.1307 & 4.1316 & 0.8106 & 0.139 & -0.0013 & 0.0157 & 0.6855 & .0015 & .0804 & 0.3005 & 8946 & 0.0814 \\
\hline Haix-Zr $\quad F^{-}$ & 0.3691 & 1.8842 & 0.9032 & .4195 & 0.3076 & 2.6564 & 0.9415 & 0.1222 & -0.0057 & 0.0509 & 0.7883 & 0.0422 & 0.0607 & 0.3101 & 0.9032 & 0.069 \\
\hline
\end{tabular}


Supporting Information Figure 1s
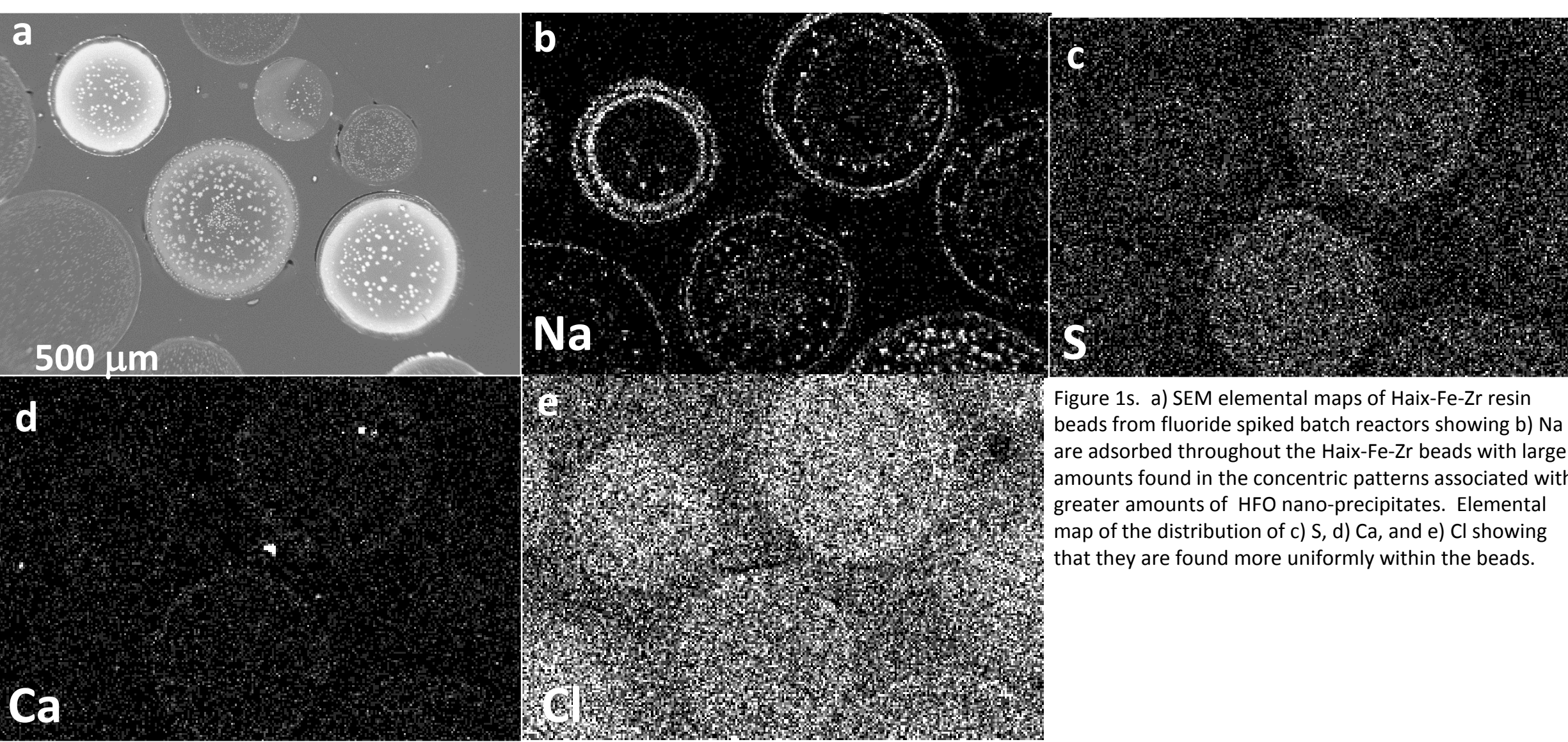

Figure 1s. a) SEM elemental maps of Haix-Fe-Zr resin

beads from fluoride spiked batch reactors showing b) $\mathrm{Na}$ are adsorbed throughout the Haix-Fe-Zr beads with larger amounts found in the concentric patterns associated with greater amounts of HFO nano-precipitates. Elemental map of the distribution of c) S, d) $\mathrm{Ca}$, and e) $\mathrm{Cl}$ showing that they are found more uniformly within the beads. 


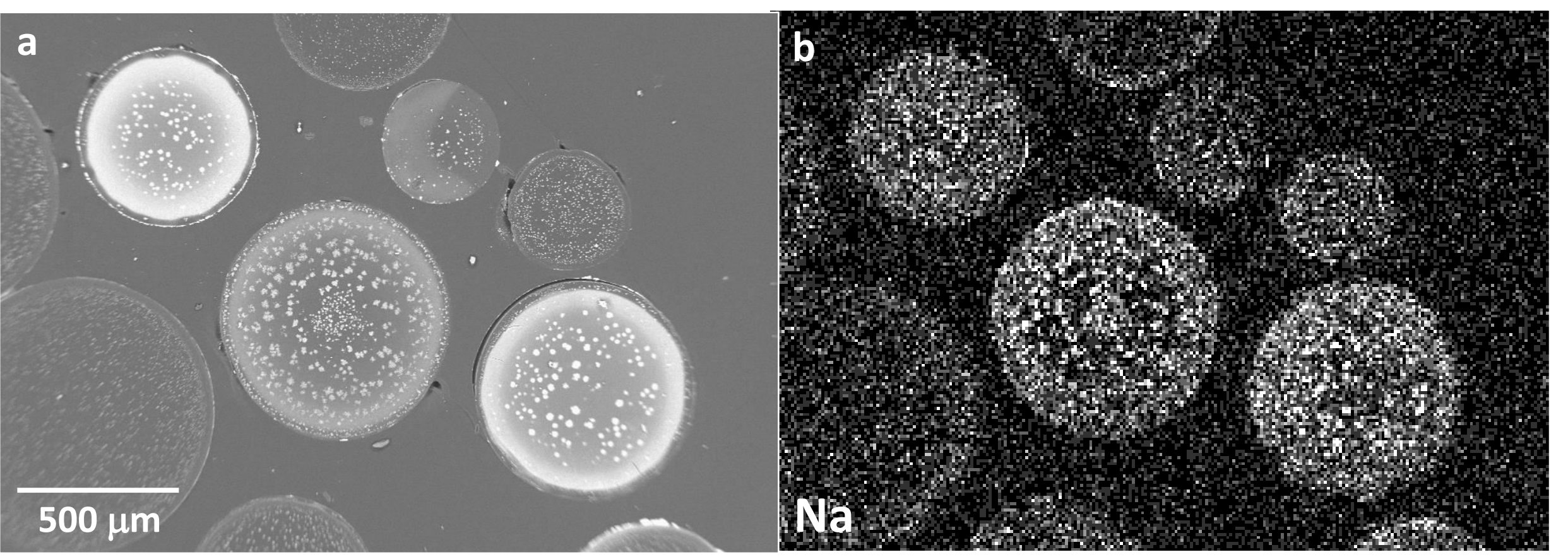

Figure 2s. a) SEM image of Haix-Zr resin beads from fluoride spiked batch reactors showing brighter areas associated with the outer edge and nano-sized HZrO which has precipitated throughout the resin beads. b) Na showing that they are associated with the Zr within the beads. 